\title{
HISTORICIDADE DA INFÂNCIA NO BRASIL
}

\author{
Historicity of Childhood in Brazil
}

\author{
Prof. Dr. Eliseudo SAlvino Gomes ${ }^{1}$ \\ Prof. Dr. José Costa Filho ${ }^{2}$ \\ Universidade Católica do Paraná - PUCPR \\ Universidad Del Museo Social Argentino - UMSA \\ salvinno@hotmail.com
}

Fecha de recepción: 01-III-2013

Fecha de aceptación: 10-III-2013

\begin{abstract}
Resumo: O presente artigo tem a finalidade de discutir diferentes concepçóes de infância; procurando entender o seu relacionamento na sociedade medieval, avaliando a sua imagem como "o jardim de infância» precocemente inserida no mercado de trabalho. Entretanto, o seu objetivo primordial é apresentar uma breve análise da história da Infância brasileira,
\end{abstract}

1 Prof. Dr. Eliseudo Salvino Gomes, Doutorado em Psicologia (Clínica) pela Universidad Pontifícia de Salamanca-UPSA (2009). Mestrado em Psicologia pela Universidade de Fortaleza-UNIFOR (2002). Membro do Grupo de Pesquisa NOUS: Espiritualidade e Sentido. Miembro del Comité Científico de la revista «Foro de Educación -Pensamiento, cultura y sociedad-». Membro do Logos \& Existência: Revista da Associação Brasileira de Logoterapia e Análise Existencial. Atualmente, Coordenador Técnico e Professor da Pós-Graduação em Análise Existencial e Logoterapia de Viktor Emil Frankl (Pontifícia Universidade Católica do Paraná-PUCPR). Orientador Educacional do Colégio Marista de Natal, Estado do Rio Grande do Norte.

2 Prof. José Costa Filho, Doutorando em Ciências Jurídicas e Sociais pela Universidad Del Museo Social Argentino - UMSA. Especialista em Direito de Processo do Trabalho pela Universidade Potiguar - UNP (2009), Especialista em Criminologia, Direito e Processo Penal pela Universidade Potiguar - UNP (2010), Especializando em Direito Constitucional e Tributário e, Direito Ambiental. Advogado e Economista. Assistente Jurídico da Ordem dos Advogados do Brasil - Seccional Rio Grande do Norte nas áreas de Direito de Família, Direito e Processo Penal e Defensor Dativo do Tribunal de Ética e Disciplina. Membro do Conselho Fiscal da Universidade Católica de Brasília. Assessor de Coordenação no Curso de Jovens e Adultos no Colégio Marista de Natal, Estado do Rio Grande do Norte. 
considerando o seu conceito de infância, bem como os aspectos da exploração do trabalho infantil, do abuso e exploração sexual infantil e da educação infantil. Destacam-se ademais as influências culturais-econômicas-históricas que podem ser observadas ao longo da estruturação do campo de estudo da Psicologia da Infância e do Direito.

Palavras-chave: Infância, Sociedade Medieval, Modernidade, História Social da Infância.

AвSTRACT: This article aims to discuss different conceptions of childhood; seeking to understand its relation in medieval society, assessing its image as "kindergarten" precociously inserted in the labor market. However, its primary goal is to present a brief review of the history of Brazilian Childhood, considering its concept of childhood, as well as aspects of the exploitation of child labor, abuse and sexual exploitation of children and early childhood education. Are also highlighted the cultural, economical and historical influences that can be observed throughout the structuring of the Child Psychology and Law field of study.

Keywords: Childhood, Medieval Society, Modernity, Social History of Childhood.

\section{INTRODUÇÃO}

A Lei no 8.069/1990, denominada de Estatuto da Criança e do Adolescente (ECA), tem uma referência do Direito Infanto-Juvenil no Brasil que se funda na doutrina da proteção integral de ambos. Essa proteçâo nasce em virtude da sua peculiar fase de desenvolvimento. Essa lei regulamenta um comando previsto nos art. 6º $7^{\circ}, 203$ e 227 da Constituição Federal Brasileira de 1988 (CF/88), assegurando o exercício dos seus direitos fundamentais.

De acordo com o -CADÊ? Crianças e Adolescentes em Dados e Estatísticas 2011-, a populaçáo infanto-juvenil brasileira soma 56.290 .168 crianças e adolescentes na faixa etária de 0 a 17 anos de idade. Deste total, 45.886. 531 (81,52\%) residem em áreas urbanas, enquanto 10.403 .637 (18,48\%) residem em áreas rurais.

Até os anos 80 no Brasil, a infância e a juventude eram contempladas especialmente pela prática de irregularidades, por isso, vistas como objetos de medidas judiciais como prescrevia a já revogada Lei no 6.697/1979, chamada de Código de Menores, que focava tanto a punição da conduta dos menores que, foi considerado por muitos doutrinadores de Código Penal de Menores, praticamente não lhes assegurava direitos.

Essa nova compreensão de atenção voltada ao desenvolvimento da infância inserida na legislação pátria atual ocorreu por força da Declaração Universal dos Direitos Humanos de 1948, Declaração Universal dos Direitos da Criança de 1959 e corroborada pela Convenção Internacional sobre os Direitos da Criança de 1989, todas adotadas pela Organização das Naçôes Unidas (ONU). O texto desta Convenção se tornou parte integrante da legislação brasileira por meio do Poder Executivo que editou o Decreto 
n o 99.710/1990 previamente ratificado pelo Congresso Nacional Brasileiro através do Decreto Legislativo no 28/90, inspirando também o ECA em 1990.

Não obstante os esforços e os resultados já alcançados no Brasil, dignos de celebração, verifica-se uma situação social ainda deplorável em relação à Infância. A exploração do trabalho infantil, os abusos e exploração sexual ainda demandam uma atuaçáo séria e constante por parte, sobretudo, do governo e da sociedade. Constatam-se também muitas crianças vivendo ainda em extrema pobreza e uma grande carência de creche e pré-escola para atender a infância no país.

\section{CONCEITO DE INFÂNCIA, DIREITOS E ACESSO À JUSTIÇA}

Os dicionários da língua portuguesa registram a palavra infância como o período de crescimento que vai do nascimento até o ingresso na puberdade, por volta dos doze anos de idade.

Segundo a Convençáo sobre os Direitos da Criança, aprovada pela Assembleia Geral das Naçóes Unidas-ONU, em novembro de 1989 e ratificada no Brasil em 1990, «criança são todas as pessoas menores de dezoito anos de idade». Já para o Estatuto da Criança e do Adolescente (1990), criança é considerada a pessoa até os doze anos incompletos, enquanto entre os doze e dezoito anos, idade da maioridade civil, encontra-se a adolescência. Etimologicamente, a palavra infância vem do latim, infantia, e refere-se ao indivíduo que ainda não é capaz de falar.

De acordo com Khulmann Jr. (1998, p. 16), infância tem um significado genérico e, como qualquer outra fase da vida, esse significado é função das transformaçóes sociais: toda sociedade tem seus sistemas de classes de idade e a cada uma delas é associado um sistema de status e de papel. Já Ariès (1978), famoso historiador francês, sublinha que a infância foi uma invenção da modernidade. Portanto, para este pensador a emergência do sentimento de infância, como uma consciência da particularidade infantil, é decorrente de um longo processo histórico, não sendo uma herança natural.

Entretanto, para Heywood (2004) havia na Idade Média uma infância, mesmo que a sociedade não tivesse tempo para a criança. Ao mesmo tempo apresenta a possibilidade de que a Igreja já se preocupava com a educação de crianças, como serviço ministerial.

O saber psicológico científico, em particular o campo da Psicologia do Desenvolvimento tem se ocupado em descrever e sistematizar as mudanças ao longo do tempo biográfico, o chamado "ciclo vital». Algumas vezes, a ênfase dos estudos e análises recaiu sobre alguns segmentos do ciclo vital, principalmente a infância e a adolescência. 
Nas palavras de Scliar (1995, p. 4), nem todas as crianças, contudo, podem viver no país da infância. Existem aquelas que, nascidas e criadas nos cinturôes de miséria que hoje rodeiam as grandes cidades, descobrem muito cedo que seu chão é o asfalto hostil, onde são caçadas pelos automóveis e onde se iniciam na rotina da criminalidade.

Para Dahlberg; Moss; Pence (2003), as novas concepçóes de infância e de criança apontam para a aceitação de uma multiplicidade e um devir que não se fecha em si mesmo. Segundo estes autores, construiu-se um ceticismo crescente sobre a modernidade e sobre suas pretensôes, desenvolveu-se, uma crescente desilusão com sua incapacidade para compreender e acomodar a diversidade, a complexidade e a contingência humanas e sua reação de tentar ordená-las a partir do que existe. O projeto da modernidade de controle através do conhecimento, a «avidez por certezas», implodiu (p. 36).

Para se estabelecerem direitos, a Lei precisa delimitar quem é criança. Então, torna-se imperioso definir até que idade se receberia tal denominação dentre as fases evolutivas humanas. O Poder Executivo ou Poder Judiciário, com base em estudo interdisciplinar, teriam que fixar qual o lapso temporal de idade para receber tal denominação; do contrário, como se trata de exercícios de direitos, o tema iria suscitar diversas polêmicas, mas, a despeito das controvérsias possíveis que iriam se sobrepor, o legislador achou por bem fixar um intervalo médio de idade como prevê o dispositivo seguinte do Estatuto em comento:

Art. $2^{\circ}$ Considera-se criança, para os efeitos desta Lei, a pessoa até doze anos de idade incompletos, e adolescente aquela entre doze e dezoito anos de idade.

Parágrafo único. Nos casos expressos em lei, aplica-se excepcionalmente este Estatuto às pessoas entre dezoito e vinte e um anos de idade.

Essa decisão de estipular uma idade foi criticada por parte da doutrina que entendia que o legislador havia levado em conta somente o aspecto cronológico, porque afirmava que se estavam desprezando os aspectos psicológico e social, enquanto outros argumentavam que não, pois essa é mais ou menos a média de idade considerada internacionalmente, apesar das diferenças culturais constatadas nos Estudos da ONU de que os limites de Idade são variáveis em um certo de número países. Estabelecer a fase da infância seria imprescindível, pois, caso deixasse se a norma aberta iria gerar mais discussão infrutífera na hora de conferir direitos, e assim foi aprovada, estabelecendo limites bem definidos.

Porém, verifica-se uma atecnia praticada pelo legislador quanto à denominação, ao prever na Ementa do Estatuto que este disporia sobre a Criança e o Adolescente, 
quando o mais adequado tecnicamente seria referir-se à Infância e Adolescência, pois guardaria mais coerência com o Direito e estrita sintonia com o próprio Estatuto, já que ao analisar o corpo da mencionada lei, se confirma que cuida de toda infância, de recémnascido, bebê até criança, tanto que a cadeira é denominada na maioria dos Cursos de Direito como Direito da Infância e Adolescência, bem como nos Cursos de Psicologia, como por exemplo, Psicologia da Infância e da Adolescência; fica assim entendido que a tutela da norma se refere à infância que termina aos 12 anos de idade incompletos.

A Constituição Federal em seu art. 227, apoiada na Convenção dos Direitos da Criança da $\mathrm{ONU}$, assegura, de forma prioritária, à criança e ao adolescente, o direito à vida, à saúde, à alimentação, à dignidade, à liberdade, à convivência familiar e comunitária, dentre outros. Esse comando constitucional garante os direitos fundamentais da criança e do adolescente.

$\mathrm{O}$ art. $5^{\circ}, \$ 2^{\circ}$, da própria Carta Magna prescreve que os direitos e garantias expressos nesta Carta não excluem outros decorrentes do regime e dos princípios por ela adotados, como é o caso dos Tratados Internacionais incorporados ao Ordenamento Brasileiro. Essa previsão foi reforçada, ampliada e detalhada no art. $3^{\circ}$ do ECA em que, dentre outros direitos fundamentais, devem ser propiciados os meios de oportunidade ao seu desenvolvimento físico, moral, espiritual e social.

Com base no art. 145 do ECA, os Estados-Membros e o Distrito Federal criaram Varas Especializadas para o exercício dos direitos da infância e da juventude que já foram criados em todas essas unidades federativas. Esse dispositivo garante os Direitos Humanos de $3^{a}$ Geração ou Dimensão, dentre os quais está o acesso à justiça.

Além das Varas Especializadas, os menores também gozam da prestação jurisdicional inerente às Varas de Famílias que prestam serviços de investigação de paternidade e pensão alimentícia, dentre outras, que na maioria, servem a eles, representados em geral por seus responsáveis.

A Carta Magna, em seu art. 5, LXXIV, assegura a assistência judiciária gratuita aos que comprovarem insuficiência de recursos. Para alguém comprovar que não tem condições de arcar com as custas processuais e honorários advocatícios, basta a declaração escrita de que não dispôe desse recurso sem prejuízo de seu sustento, como prevê o art. $2^{\circ}$ da Lei no $1.060 / 1950$, que regulamentou a matéria até hoje.

O caput do art. 141 do ECA garante com prioridade o acesso da criança e do adolescente à Justiça de forma gratuita, os quais serão assistidos pela Defensoria, pelo Ministério Público, Poder Judiciário e Outras entidades como a OAB - Ordem dos Advogados do Brasil, especialmente por meio das suas seccionais sediadas nos Estados-Membros e em cujos Municípios ainda há algumas subsecionais, além das Faculdades e Universidades. 
Ressalta-se, que como são menores de idade, as crianças são representadas por seus pais, tutores, curadores ou outros responsáveis bem como os que detêm a guarda.

\section{EXPLORAÇÃO DO TRABALHO INFANTIL}

A história da criança no Brasil é discutida por Ramos (2000), quanto às condiçóes de vida das crianças europeias trazidas para cá no século XVI, e por Priore (2000) quanto ao cotidiano das crianças livres ou escravas no Brasil Colônia e Império. A entrada na Modernidade náo trouxe muita diferença para todos os pequenos brasileiros. $\mathrm{O}$ sonho de infância feliz não parece ter sido vivido pelas crianças operárias da cidade de São Paulo recém-industrializada como aponta Moura (2000) ou mesmo das crianças trabalhadoras do nosso país (Rizzini, 2000; Abreu, 2000).

Parte da legislação em análise se destinou a regulamentar uma situação que, embora tenha apresentado enormes avanços, ainda constitui um problema não solucionado satisfatoriamente que é a questão da exploração do trabalho infantil que consiste na sujeição ao trabalho de pessoas na fase da infância com a finalidade de lucro. Essa prática se encontra presente em quase todos os países subdesenvolvidos e em desenvolvimento, sem contar com outras formas de violências presentes nesses países.

Vale salientar que o período colonial brasileiro foi marcado pela ausência de uma concepçáo de infância que assegurasse às crianças o direito de serem efetivamente crianças, vivendo em companhia de suas famílias e tendo acesso à alimentação de qualidade, moradia digna, saúde e educação sem distinção social ou racial.

O Decreto no 99.710/1990 promulga a Convenção sobre os Direitos da Criança da ONU, ratificado pelo Decreto Legislativo no 28/1990 no país. Andou na mesma linha o posicionamento do parlamento brasileiro ao ratificar também as Convençóes $\mathrm{n}^{\circ}$ 138 e 182 da OIT - Organizaçáo Internacional do Trabalho que respectivamente estabelecem a idade mínima para admissão ao trabalho e a proibição das piores formas de trabalho infantil e sua eliminação. Arrimado nesses institutos, dentre outros, Governo Federal cria um Plano Nacional de Prevenção e Erradicação do Trabalho Infantil e Proteção ao Adolescente.

O princípio $9^{\circ}$ da Declaração Universal dos Direitos da Criança adotada em 1959 pela Assembleia Geral da ONU afirma que não será permitido o trabalho de criança antes da idade adequada. A OIT, preocupada com o tema, estabelece a idade de 16 anos, porém, diante da dificuldade de consenso nas diferentes culturas, permite que seja iniciado a partir dos 14 anos de idade, o que aconteceu por meio da Convenção no 138 de 1973, orientaçóes que inspiraram o comando da norma constitucional brasileira (art. $7^{\circ}$, XXXII, da CF/88) que estabelece o seguinte: 
XXXIII - proibição de trabalho noturno, perigoso ou insalubre a menores de dezoito e de qualquer trabalho a menores de dezesseis anos, salvo na condição de aprendiz, a partir de quatorze anos;

$\mathrm{O}$ art. 60 do ECA reproduz a norma constitucional e regulamenta, com vários detalhamentos nos seus artigos seguintes, o direito à profissionalização do menor de 18 anos de idade, a partir dos 14 anos, na condição de aprendiz. Nesta fase se trata de trabalho educativo que consiste na atividade laboral, pautado por exigências pedagógicas para o desenvolvimento pessoal e social do educando como assegura o art. $68, \S 1^{\circ}$ do Estatuto analisado. O Parágrafo único do art. 403 do Decreto-Lei no 5.452/43, conhecida como a CLT - Consolidação das Leis do Trabalho, assim dispóe:

Parágrafo único. $\mathrm{O}$ trabalho do menor não poderá ser realizado em locais prejudiciais à sua formação, ao seu desenvolvimento físico, psíquico, moral e social e em horários e locais que não permitam a frequência à escola.

Para a implementação da previsão legal, foi criado o Programa de Educação Tutorial (PET) por meio da Lei no 11.180/2005 cujo art. 18 inseriu o art. 428 na CLT para melhor regulamentar o contrato de trabalho de aprendizagem para o maior de 14 anos, visando evitar abusos contra crianças e contribuindo de fato com a formação técnica, física, moral e psicológica do aprendiz. Apesar da atuação permanente do Conselho Tutelar e do Ministério Público (MP) e outras organizaçóes contra a exploração do trabalho infantil, isso ainda se verifica no Brasil, com mais ênfase em determinadas regióes ou setores da atividade econômica e mesmo em atividade ilícita.

O trabalho infantil era visto culturalmente como forma inicial de educação doméstica e de provimento material do orçamento da família, difícil de ser erradicado de um momento para outro, motivo pelo qual precisa ser reeducada a sociedade para fazer entender que essa fase não é apropriada para o trabalho, sobretudo de forma obrigatória, muito menos trabalho penoso ou desumano. A Justiça tem se voltado mais para um terceiro que utiliza a mão-de-obra infantil e quase nada quando o trabalho é exercido sob subordinação familiar. A esse respeito, o Plano de Prevenção e Erradicação do Trabalho Infantil e Proteção ao Trabalhador Adolescente, p. 13, proposto pelo Governo Federal, disponibilizado na página do Ministério do Trabalho e Emprego (MTE) explica com a explanação a seguir da situação vivida historicamente:

O trabalho infantil é um fenômeno social presente ao longo de toda a história do Brasil. Suas origens remontam à colonizaçáo portuguesa e à implantação do regime escravagista. Crianças indígenas e meninos negros foram os primeiros a sofrerem os rigores do trabalho infantil em um país que, de início, estabeleceu uma estrutura de produção e distribuição de riqueza fundamentada na desigualdade social. $\mathrm{O}$ posterior 
processo de industrializaçáo correlato da transformação do Brasil em uma economia capitalista manteve intactas tais estruturas, obrigando o ingresso de grandes contingentes de crianças no sistema produtivo ao longo do século XX.

A questão cultural da exploração do trabalho infantil está tão arraigada, que uma pesquisa apresentada pelo Instituto de Pesquisa Econômica Aplicada (IPEA) constatou que $55 \%$ dos estudantes da $9^{\circ}$ ano do Ensino Fundamental desejam trabalhar; não é demais enfatizar que boa parte dessas crianças ou adolescentes está fora da faixa recomendada, o que pode contribuir para esse percentual elevado, mesmo sabendo que a grande maioria deles pertence a famílias de baixa renda, mesmo sabendo também que se está diante de programas de transferência de renda mais vultosos que o Brasil já conheceu.

Esse é um retrato muito importante para entender e enfrentar a cultura laboral infantil no Brasil. É possível discutir qual a idade mais adequada para a educação ao trabalho, mas uma coisa é certa: a idade inapropriada afeta não somente a saúde, como também redunda em dificuldade ou impossibilidade de conciliá-lo com os estudos, o que tem gerado enormes prejuízos para as crianças e para a sociedade, resultando em adultos analfabetos ou semialfabetizados que têm dificuldades de se realizar profissionalmente, além de depender, em regra, de muitas políticas governamentais assistenciais.

Com base na Convenção no 182 da OIT, além das demais responsabilidades, o Brasil criminalizou a conduta que reduz alguém à condição análoga à de escravo; essa denominação consiste em submeter pessoa a trabalhos forçados, jornadas exaustivas, em condiçôes degradantes, restringindo sua locomoção por algum motivo, conforme tipificaçáo prevista no art. 149 do Código Penal. O Inciso I do $\$ 2^{\circ}$ deste artigo prevê expressamente o aumento de pena quando o crime é cometido contra criança ou adolescente.

Várias açóes foram inseridas no Plano Nacional de Prevenção e Erradicação do Trabalho Infantil e Proteção ao Adolescente do Governo Federal, dentre as quais se acham o monitoramento e avaliação do trabalho infantil, capacitação dos conselheiros tutelares, encaminhamento de crianças e adolescentes explorados no trabalho, incentivo à produção acadêmica sobre tema do trabalho infantil, Inclusão nos currículos das escolas preparatórias à Magistratura e Ministério Público de temas relacionados com o ECA, criação de rotinas para a assistência na rede do SUS - Sistema Único de Saúde, Articulação intersetorial para açóes de combate ao trabalho precoce, Implementação das açôes constantes no Plano de Enfrentamento da Violência Sexual Infanto-Juvenil, dentre outros.

Os dados estatísticos em geral são colhidos em conjunto, isto é, crianças e adolescentes, de modo que só é possível constatar um indicativo que aponta que vem se reduzindo o trabalho infantil no Brasil, no conjunto isso vem acontecendo. O Plano de Prevenção e Erradicação do Trabalho Infantil e Proteção ao Trabalhador Adolescente, 
p. 14 a 17 do MTE afirma com base nas informaçóes de prevenção e erradicação do trabalho infantil que na faixa etária de 05 a 14 anos, no período de 1992 a 2002, houve uma redução de 4,1 milhôes para 2,1 milhôes. As pessoas nessa faixa atuam principalmente em trabalho doméstico, agrícola e em outros por conta própria, ou sob a orientação dos seus responsáveis e que grande parte deles está fora da escola ou com frequência irregular, e muitos estão com a escolarizaçáo muito abaixo da sua idade recomendada.

Outra série histórica constante no Mapa de Indicativos do Trabalho da Criança, e do Adolescente, gráfico um (1), p. 15, elaborado pelo MTE indica que em 2004 em outras faixas etárias, demonstra que, no período de 1995 a 2002, houve uma diminuiçấo de 5.147.964 para 2.988.294, correspondendo a 41,95\% da população brasileira de 05 a 15 anos. Como a pesquisa novamente não separou crianças de jovens, não é possível calcular com exatidão o quanto o trabalho infantil no Brasil nesse período vem declinando.

O Quadro Geral de Operações de Fiscalização para Erradicação do Trabalho Escravo em suas páginas 1 a 2 do MTE apresenta a atuação da fiscalização empreendida por parte do Governo Federal contra o trabalho infantil, chegou aos seguintes resultados de 1995 a 2012: em 1995 foram realizadas 11 operaçóes, inspecionando 77 estabelecimentos, resgatando 44 trabalhadores; não foi disponibilizado o valor de multas, mas foram aplicados 906 autos de infração. Já em 2012, foram realizadas 135 operaçôes, 241 inspeçóes, resgataram 1.461 trabalhadores, lavrados 3.468 autos de infração e pagos $\mathrm{R}$ \$ 8.660. 780,05 em indenização rescisória trabalhista, sem contar com as multas dos auditores do trabalho.

Os dados apresentados acima indicam que vêm sendo utilizadas açóes tendentes a combater a exploração do trabalho infantil no Brasil; muitos questionam que deveriam andar num ritmo maior e que deveria haver um empenho maior do governo e da sociedade.

\section{ABUSO E EXPLORAÇÃO SEXUAL INFANTIL}

$\mathrm{O} \$ 4^{\circ}$ do art. 227 da $\mathrm{CF} / 88$ previu a punição severa a quem pratica abuso, violência ou exploração sexual da criança e do adolescente. São direitos fundamentais previstos posteriormente na Convenção sobre Direitos da Criança da ONU adotada em Assembleia Geral da ONU em 1989. A matéria já havia assumido o status constitucional, integrando diretamente essa concepção de direitos humanos pelo legislador constituinte.

Em defesa da proteção integral e do aprimoramento do sistema proteção à infância, foi criada a Lei $n^{\circ} 12.696 / 2012$, que obriga a existência pelo menos um Conselho Tutelar em cada Município composto por cinco (5) membros escolhidos pela população para mandato de quatro (4) anos, permitida uma única reeleição consecutiva. 
Para combater de forma veemente essa modalidade de violência, foi necessário criminalizar a conduta de quem abusa e explora sexualmente crianças e adolescentes. Havia até 2009 a previsão de violência presumida no art. 224 do Código Penal Brasileiro contra menor de 14 anos, já que o Sistema Penal Brasileiro é biopsicológico exigindo requisito biológico e psicológico para que alguém cometa crime; já que para a prática de conduta delituosa, Isto é, ação ou omissão humana, consciente e voluntária, dirigida a uma finalidade, são requisitos necessários para obter um resultado ilícito, como afirma Capez (2003). Como o menor de 14 não dispóe dessas faculdades, ainda que tenha desejo, por náo possuir vontade segundo nosso ordenamento penal que exige que detenha as condiçóes biológicas e psicológicas para um discernimento que possa sustentar uma decisão imputável, de modo que quem pratica contração carnal contra menor dessa idade comete crime de estupro; destaca-se que o conceito de estupro foi ampliado, incluindo outras condutas correlatas como atos libidinosos.

Como aponta Nucci (2007) em sua obra Código Penal Comentado que parte da doutrina penal resistiu muito à concepção de presunção de violência no Direito Penal, ainda que excepcionalmente, por confrontar com o princípio da presunção de inocência e da responsabilidade subjetiva adotada no Ordenamento Penal Brasileiro. Mas, a maioria da doutrina e jurisprudência brasileiras considerou a matéria constitucional em relação aos menores de 14 anos, aos que sofrem alienação ou debilidade mental e para os que, por qualquer outra causa, não possam oferecer resistência por representar, as três hipóteses representam uma exceção ao conceito de violência no Direito, é a porta estreita do pensamento que visa à para a proteção deles.

A matéria é tão palpitante e polêmica, que gerou controvérsias por constituir um dos pilares do Direito Penal, denominado de inimputabilidade que consiste na ausência do discernimento para assumir a responsabilidade, ou seja, desprovido de condição pessoal para compreender o caráter ilícito do fato e se posicionar segundo esse entendimento, ou seja, por não poder declarar consentimento válido nos relacionamentos sexuais e preveni-los da inconsequência dos seus atos, a qual pudesse comprometer parte de seu futuro. Então, surgiu ainda a discussão sobre se a presunção seria absoluta ou relativa.

Com o advento da Lei no $12.015 / 2009$, foi tipificado o crime de pedofilia, e a denominação passou a ser Crime Contra Vulnerável prescrita no art. 217-A a 218-B do Código Penal. De presunção absoluta ou relativa, já que havia resistência em conceber violência presumida, uma vez que a violência deve ser real, física ou psicológica, passou então, segundo Nucci (2010) a se discutir se a vulnerabilidade é absoluta ou relativa, ou seja, a polêmica sobre o tema continua porque o fundamento descrito no tipo penal anterior continua o mesmo, não foi capaz de ilidir os fundamentos da realidade fática descrita. O ECA, em seu art. 241, prevê diversas formas de crime contra a liberdade sexual da criança e do adolescente. 
O Supremo Tribunal Federal (STF), por meio de suas Turmas, tem proferido julgados dissonantes em relação à presunção. Uma Turma diz que é relativa, outra que é absoluta, e isso tem gerado uma insegurança no tocante a abusos contra menores, especialmente nessa fase do desenvolvimento em discussão. $\mathrm{O}$ posicionamento de que a presunção é relativa consiste em que se um menor de idade conseguir passar por maior em razão de sua compleição física ou se já vivia experiências sexuais, inclusive vítima de exploração de prostituição, não poderia ser considerado crime quando uma maior de idade viesse com ela manter contatos sexuais.

A defesa dessa linha de raciocínio tem gerado algumas notas de repúdio por algumas entidades, nas quais seus membros manifestaram contra uma decisão do STJ Superior Tribunal de Justiça e o TJMT - Tribunal de Justiça do Estado do Mato Grosso que absolveram dois indivíduos réus no processo de exploração sexual de duas adolescentes. O caso já havia ensejado uma CPMI - Comissão Parlamentar Mista de Inquérito na seara política em 2003. Muitas entidades insurgiram contra tal compreensão por considerá-la, em parte, moralista e estimuladora de abuso e exploração sexual contra os menores.

No voto do Ministro Relator Marco Aurélio de Mello sobre um julgado no qual afirma que uma criança com apenas 12 anos de idade levava uma vida promíscua, segundo defesa do acusado, ressalta o Ministro a presunçáo prevista no Código Penal não pode também desconsiderar essa realidade social atual de experiência sexual, mesmo que seja nessa tenra idade porque houve uma mudança de costumes que permite que essa criança entenda e trate do assunto com desenvoltura e que não pode mais ser considerada tâo indefesa quando ela mesma consente.

A Terceira Turma do STJ surpreendeu novamente no dia 27/03/2012 ao decidir em outro caso em que a decisão admite a presunção relativa no crime de estupro, uma vez que as três menores afirmaram que já se dedicavam às práticas de atividades sexuais há bastante tempo, de modo que os magistrados inocentaram o réu. Tudo isso acontece porque no tipo penal do estupro se exige violência física ou grave ameaça, sendo esta entendida como violência moral e psicológica grave e que possam ser demonstradas, já que até 2009 constava no tipo presumido e o processo tramitava desde então, sendo que nova lei penal não pode retroagir para prejudicar o réu; e para o caso náo se havia constatado violência física ou grave ameaça como elementar do tipo previsto, então não seria estupro. A grita foi grande por parte de diversas entidades, uma vez que já havia previsão da norma penal sobre violência presumida, tipificada nessas hipóteses excepcionais. Há que se ressaltar que foi uma decisão de Turmas. Espera-se com certa urgência uma decisão plenária sobre esse entendimento para pacificar a situação. 
Cabe um esclarecimento ao leitor quanto ao tipo penal, que náo se trata de gíria, consiste no modelo elaborado pela lei penal, descrevendo com precisão a conduta criminosa ou da conduta permitida. E somente quando a conduta de uma pessoa se ajusta perfeitamente ao protótipo legal, chamada de tipicidade é que se pode afirma ter existido crime. De modo que fato típico é a conduta humana que se enquadra com perfeição aos elementos contidos no tipo penal. Constituem elementos do fato típico: a conduta, o resultado, o nexo causal e a tipicidade. Não atendendo a esses requisitos o fato é atípico, isto é, não é crime. Crime é atitude mais violenta com que um indivíduo pode agredir a sociedade e a sançáo penal é o modo mais agressivo que Estado se serve para interferir na vida privada. Por isso, o direito penal possui caráter residual, somente pode ser utilizado quando nenhum outro ramo do Direito e dos demais saberes dispóem de medidas que possam solucionar de modo aceitável um dado ato que viola demais o convívio social. Toda a exigência para estabelecer tipo legal decorre do princípio da reserva legal, da legalidade estrita e da anterioridade e da segurança jurídica. Tudo isso, em homenagem à garantida em favor da dignidade humana, afastando o máximo possível a atuação arbitrária de autoridades e de outros indivíduos que possam engendrar uma conduta criminosa contra alguém inocente, numa luta incessante para preservar a liberdade e a vida, os bens jurídicos mais caros dentro do Direito. Embora não seja a regra entre países democráticos, ainda existem os que utilizam a pena capital como resposta a uma agressão capital, sob grande pressão da ONU e movimentos sociais na tentativa de eliminar esse tipo de sanção.

A punição contra os abusos sexuais aumentou com o advento da lei contra pedofilia, atuação enérgica do MP e pressão da sociedade nos seus diferentes segmentos contribuíram para esse resultado.

O Decreto no 5.007/2004 promulgou no Brasil o Protocolo sobre a Convenção dos Direitos da Criança que proíbe a venda de criança, a prostituiçáo e a pornografia infantil. É uma busca incessante do Poder Público e de organizaçóes que atuam nesse segmento em oferecer vida com dignidade às crianças, entre as quais está a OIT, que vem realizando uma excelente parceria com o país, razáo pela qual o Brasil adota mais uma vez em seu ordenamento interno esse protocolo facultativo, do ponto de vista da soberania nacional e independência dos povos, mas uma obrigação moral na defesa da dignidade da infância.

O ECA em seu art. 244-A tipifica como crime submeter criança ou adolescente à prostituição ou à exploração sexual. $\mathrm{O}$ bem jurídico em causa é a sua moralidade sexual e a formação de sua personalidade que são partes integrantes da sua dignidade em razão de sua particular fase de desenvolvimento que estão vivenciando. Essa norma procura combater uma indústria fomentada no mundo inteiro em que são ofertadas pessoas nesse estágio de vida, sobretudo, oriundas de países subdesenvolvidos ou em 
desenvolvimento como o Brasil. Indústria alimentada pelo turismo sexual e pela produção pornográfica.

Com as políticas públicas articuladas no Plano Nacional de Enfrentamento da Violência Sexual Infanto-Juvenil, foi possível perceber inúmeras necessidades que também suscitaram o Programa Nacional de Enfretamento da Violência Sexual que objetiva integrar diversos programas e açôes governamentais e não governamentais. Há de distinguir abuso sexual de violência sexual. No primeiro, é necessária uma relação de poder ou confiança como acontece com aquele que é responsável por uma criança, mesmo que não esteja presente a violência física, mas quase sempre a psicológica, mas sem relação comercial, mais comum sua ocorrência no seio familiar e vizinhança. Na última, faz-se presente, de forma notória, o lucro proveniente dos que exploram a atividade ilícita, mesmo que seja com aquiescência dos responsáveis.

\section{EDUCAÇÃO INFANTIL}

Até o final do século XIX e início do século XX não houve nenhuma intenção genuinamente educacional voltada para as crianças de zero a seis anos e, em se falando da criança negra, nas primeiras décadas do século XIX torna-se figura invisível e de pouca importância na historiografia brasileira. Ao atingir a idade de sete anos, as crianças negras iam trabalhar e as crianças brancas estudar.

Rousseau (1995) em seu livro Emílio ou Da Educação diz: Amai a infância; favorecei seus jogos, seus prazeres, seu amável instinto. Quem de vós não se sentiu saudoso, às vezes, dessa idade em que o riso está sempre nos lábios e a alma sempre em paz? Por que arrancar desses pequenos inocentes o gozo de um tempo táo curto que lhes escapa, de um bem tão precioso de que não podem abusar? (p. 61).

No Brasil, antes da Constituição de 1988, a criança ainda não era reconhecida como cidadá possuidora de direitos assegurados por lei, enquanto na França por volta de 1870 as salas de asilo eram abertas ao público independente das máes trabalharem ou não fora de casa e já havia intenção de elevar a criança oriunda da classe proletária à categoria de cidadá.

Contudo, a Educação Básica brasileira compreende a Educação Infantil, Fundamental e Média segundo os arts. 24 e 29 da Lei 9.394/1996, conhecida como LDB - Lei de Diretrizes de Bases da Educação. Esses níveis de educação foram durante muito tempo relegados a um segundo plano, pois a preocupação maior se voltava para a educação superior, por necessidade de profissionais em que se presenciou uma grande demanda até a década de 90 em descompasso com a oferta, destinada especialmente a uma elite. Porém, só recentemente, quando o país se defrontou com profissionais mal preparados, é 
que a educação básica se tornou uma pauta de preocupação do governo, pois sem a qual não há como se obter uma formação qualificada de profissionais.

A educação infantil, que integra o objeto deste trabalho, é subdividida em duas fases: Creches e Pré-escola conforme art. 30 da LDB. Embora tal fase receba essa denominação, a infância alcança parte do Ensino Fundamental que agora tem duração de nove (09) anos, iniciando a partir dos seis (06) anos de idade e é obrigatória, segundo art. 32 dessa mesma Lei. $\mathrm{O}$ ensino básico se tornará obrigatório para os que estão na idade escolar recomendada e os que estão fora, são acolhidos pela EJA - Educação de Jovens e Adultos. Decorre dessa obrigatoriedade do ensino básico até os 17 anos, isto é, da creche ao médio, que será ofertado para todos a partir de 2016, de acordo com a Emenda Constitucional no 59/2009.

Ser obrigatório o ensino básico faz uma enorme diferença para o Direito, por poder ser exigido tanto dos pais ou responsáveis quanto do Estado, que deve assegurar a todos nesse nível, sob pena de ser o Município impelido a cumprir judicialmente sua obrigação, já que no momento é de sua responsabilidade o ensino fundamental, oferecendo vagas a todas as crianças que estão nessa fase de estudo. Enfatiza-se que atualmente é a única fase da educaçáo básica que é obrigatória. Essa obrigatoriedade é que autoriza o MP - Ministério Público, Defensoria Pública, OAB - Ordem dos Advogados do Brasil e Entidades que dispóem dessa legitimidade a interpelarem os Entes Públicos a cumprir sua prestação de serviço essencial, inclusive mediante intervenção da Uniâo nos Estados e Distrito Federal como assegura o previsto no art. 34, IV, e, da CF/88.

No que diz respeito do estabelecimento de educação, denominado creche, já experimentada no país deste o período imperial, tornou-se uma prestação de serviço mais marcante pelo Estado a partir dos anos $70 \mathrm{com}$ a industrialização do Brasil para atender filhos de operário. Tinha mais uma função assistencialista, benefício que também adveio, por via colateral, dos esforços dos movimentos feministas da classe média que usufruía dos serviços dessas famílias. Mais recentemente virou uma necessidade utilizada pelos filhos das famílias enquanto as mulheres trabalham. O atual Governo Federal vem procurando oferecer recursos vinculados, não podendo ter outro destino, para os Municípios que respondem por esse nível educacional para ampliar o número de vagas da educação de creche e pré-escola.

Intenção bem distinta do que pensou o pedagogo alemão August Fröbel no século XIX, que concebeu o Jardim de Infância como finalidade de atenção à criança pela especial fase em que vive. Ao realizar estudos sobre as diversas fases de desenvolvimento, constata-se que naquela, se daria a vivência do lúdico com desenhos, brinquedos, primeiro contato orientado com o próprio corpo e, a partir daí, o desenvolvimento integral da criança. Na compreensão desse educador, o foco era a infância, mas no caso brasileiro, 
a atençáo se volta primeiro para a mãe que precisa trabalhar, chegando ao filho, por via oblíqua. O que parece indicar o motivo do pouco caso que se conferia ao tema. Porém, agora, há sinais visíveis de cuidados tanto a máe quanto o filho nessa fase de creche e pré-escola.

A Educação Superior, Ensino Médio e Fundamental vêm sendo ofertados de forma bastante satisfatória no Brasil, ultimamente em termo de quantidade, mas não se pode dizer o mesmo no que se refere às Creches e às Pré-escolas. Não obstante o Brasil vem fazendo um trabalho importante para a redução do analfabetismo no Brasil, tanto que atualmente já não se realça o acesso à educação, mas a qualidade na educação. Porém, no que tange à Educação Infantil ainda é muito incipiente.

O Governo Federal criou o Bolsa Família por meio da Lei no 10.836/2004, que unifica outros Programas Nacionais como o de Renda Mínima, vinculado ao Bolsa Escola. O Programa Nacional de Acesso à Alimentação bem como o Programa Nacional de Renda Mínima vinculada à Saúde, dentre outros. Essa assistência de renda mínima se destina a famílias em situação de extrema pobreza que tenham gestantes, nutrizes, crianças entre 0 e 12 anos ou adolescentes até 15 (quinze) anos, em algumas situaçôes podendo alcançar jovens de até 17 anos. Esse benefício está condicionado à matrícula e presença escolar, o que tem representado um desenvolvimento social importante para o país.

A Alimentação oferecida a essas famílias já beneficiou uma parcela importante da população que vivia em extrema pobreza por meio de Convênios entre União, Estados e Municípios, sendo este último ente público o executor. Além da nutrição, foi instituído o programa de saúde, que visa contribuir com a formação integral do educando da rede pública de educação básica. O Sistema Único de Saúde (SUS) se articula com as redes de educaçáo pública, o denominado de Programa de Saúde na Escola (PSE), integrando educação e saúde, promovendo saúde nutricional, alimentação saudável, avaliação oftalmológica, auditiva, bucal, saúde sexual e reprodutiva, prevenção contra álcool, drogas, dentre outros.

Estudos realizados pelo Governo Federal, a contrário senso do que se imaginava, demonstraram que as crianças na fase Jardim e Pré-Escola de famílias extremamente pobres se encontravam em situaçáo ainda mais vulnerável e para tanto foi criado o Programa que recebe a designação de Brasil Carinhoso. O Governo Federal vem ampliando a rede de proteção social porque era, no Brasil, extremamente deficitária. Esse benefício complementa o Bolsa Família, mas voltado à primeira infância.

$\mathrm{Na}$ Síntese de Indicadores Sociais do Instituto Brasileiro de Geografia e Estatística (IBGE), em 2009, na tabela 6.3, aponta que as crianças de 0 a 6 anos de idade frequentaram Creches ou Escola nos seguintes percentuais: de 0 a 3 anos, somente 18,1\% e de 4 a 
6 anos, representavam $79,8 \%$, resultando numa frequência média de menos de $50 \%$ no intervalo etário de 0 a 6 anos. Considerando as maiores diferenças nas cinco regióes do Brasil, na primeira faixa etária, ou seja, de 0 a 3 anos, apenas 8,4\% estão frequentando no Norte, ao passo que na região Sudeste esse percentual é $22 \%$.

Constatou-se também, por meio da Síntese de Indicadores Sociais do IBGE, em sua tabela 6.4, que nas famílias de baixa renda, a frequência é menor ainda, no período acima citado foi possível verificar que, na faixa etária de 0 a 3 anos cuja família possua rendimento até $1 / 2$ salário mínimo, a frequência é de $12,4 \%$ e quando a renda fica entre 2 e 3 salários mínimos, é de 36,4\%. O Censo Demográfico 2010 do IBGE constatou que as crianças de 0 a 5 anos que viviam em habitaçáo com saneamento inadequado e cujos responsáveis eram analfabeto, eram de 24,7\% em 2000, caindo para 4,6 em 2010. Com base nessas informaçóes, o Governo Central começou oferecer também apoio financeiro a partir de julho de 2012 aos Municípios e Distrito Federal para as crianças de 0 a 4 anos, mesmo que já recebam o Bolsa Família, para manutenção e desenvolvimento da educação infantil em creches, através da Ação Brasil Carinhoso.

A taxa de analfabetismo vem caindo no Brasil, conforme o Censo 2010, que estima que $90 \%$ da populaçáo com dez (10) ou mais anos são alfabetizadas. Porém, na Região do Semiárido brasileiro, a situação ainda é bem diversa, vários Municípios ostentam uma taxa muito elevada para a faixa etária em questão, como se constata nos Municípios dos seguintes Estados: Estado do Rio Grande do Norte: Coronel João Pessoa (29,2\%), Pedra Preta (35,3\%), Japi (41,4\%), Jardim de Angico (42,6\%). Estado do Piauí: São Julião (31,7\%), Caracol (31,8\%), Pavussu (31,9\%), Assunção do Piauí (33,7\%). Estado de Pernambuco: Buíque (27,7\%), Manari (31,3\%), Águas Belas (31,7\%), Inajá (44,8\%). Estado da Paraíba: Cacimbas (26,4\%), Tenório (26,4\%), Poço Dantas (27,3\%), São José de Caiana (28,7). Estado de Alagoas: Lagoa da Canoa (31,6\%), Mata Grande $(32,2 \%)$, Olho d'Água do Casado (33,7), Traipú (40,6\%). Estado de Sergipe: Monte Alegre de Sergipe (25,9\%), Canhoba (31,85). Estado da Bahia: Itapicuru (26,4\%), Araci (29,2\%), Pilão Arcado (32,6\%), Pedro Alexandre (38,7\%). No Estado do Ceará a situação é melhor, somente o Município de Icó apresenta um percentual de 27,1\%. O Semiárido que alcança o Estado de Minas Gerais está com uma taxa de analfabetismo abaixo dos $14 \%$.

Com a taxa média de $90 \%$ de alfabetização de pessoas com dez (10) ou mais anos, hoje no Brasil, já se permite voltar sua atenção à qualidade da educação, inclusive que as crianças sejam alfabetizadas na idade recomendada. Com esse fim, foi editada a Medida Provisória no 586/2012, que cria um Pacto Nacional pela Alfabetização na Idade Certa; essa preocupação se verifica com mais frequência em relação ao alunado que utiliza a rede pública de ensino. 


\section{CONSIDERAÇÕES FINAIS}

Assim, a doutrina da proteção integral voltada à infância, aplicada no Brasil a partir dos anos 90, representou uma conquista social incomensurável, resultado que teve, em grande parte, a contribuição dos entes multilaterais como a ONU e OIT. Essa particular fase de desenvolvimento conquistou inúmeros direitos que podem ser constatados, mas ainda há um grande desafio a ser percorrido pelo país.

Diversas políticas foram criadas em defesa da dignidade da infância, especialmente, destinadas à alimentaçáo, à saúde, à educação e ao combate à violência sexual e à exploração do trabalho infantil. Nessa luta vêm se mostrando também exitosas as conquistas de proteção contra a violência sexual infantil.

É preciso enfatizar que tanto a exploração sexual quanto a do trabalho infantil têm a finalidade de lucro. Respeitadas as orientaçóes culturais, já que dentro da família, os menores começam a trabalhar muito cedo, contudo, faz-se mister também oferecer meios de referências para se encontrar novas alternativas aceitáveis de uma idade mais condizente ao trabalho formal, respeitando a saúde e desenvolvimento da infância presente com perspectivas de estima profissional e inserção social futura.

As conquistas econômicas, sociais, culturais e nutricionais vividas pelos menores de idade permitem um desenvolvimento biológico e psicológico numa idade ainda precoce para o que se concebia até entáo como apropriado, propiciando a eles começarem a experimentar uma vidada sexual cada vez mais cedo. Algo bem distinto de exploração sexual infantil, mas não deixa de gerar em implicaçôes recíprocas entre ambas, sem contar com um mercado de exploração sexual infantil, desde a indústria pornográfica ao comércio sexual.

Em relação ao trabalho constata-se uma tripla exploração: sujeição de menores à atividade laboral abaixo idade mínima com todos os seus reflexos, jornada tão longa quanto à dos adultos e recebem remuneração muito inferior aos daqueles, quando não trabalham apenas para obter a alimentação. Não há dúvida de que é relevante a educação para o trabalho, faz-se necessário, então, encontrar uma idade razoável para o início de um ofício formal.

O trabalho informal pode submeter a infância a uma situação tão vexatória quanto uma quanto à exploraçáo infantil. É imperioso conciliar a fase de desenvolvimento do menor de idade com a aprendizagem para o trabalho numa idade adequada, da mesma forma que se procura a alfabetização numa idade certa, é preciso aprendizagem laboral na idade recomendada para que tenham oportunidade profissional na idade adulta. 


\section{REFERÊNCIAS}

Abreu, M. (Org.) (2000). Meninas Perdidas. In: Priore, M. História das Crianças no Brasil. São Paulo: Contexto, pp. 289-316.

Afonso, J. da Silva (2006). Comentário Contextual à Constituição. 3a. ed. São Paulo: Malheiros.

Almeida, A. P. de (2011). CLT Comentada. 9a. ed. São Paulo: Saraiva.

Ariès, P. (1978). A História social da criança e da família. Rio de Janeiro: Guanabara.

Bastos, M. (2001). Jardim de Crianças: o pioneirismo do Dr. Menezes Vieira (1875-1887). In: MONARCHA, Carlos (Org.). Educação da infância brasileira (1875-1983). São Paulo: Autores Associados.

Brasil (1990). Estatuto da Criança e do Adolescente. Brasília: CBIA.

. (1996). Ministério da Educação. Lei de Diretrizes e Bases da Educação Nacional. Lei no 9.394, de 20 de dezembro de 1996.

Brasil. Lei n. 12.696, de 25 de julho de 2012. Altera os arts. 132, 134, 135 e 139 da Lei $n^{\circ}$ 8.069, de 13 de julho de 1990 (Estatuto da Criança e do Adolescente), para dispor sobre os Conselhos Tutelares. Diário Oficial da União, Brasília, 26 de julho de 2012.

. Lei n. 12.015, de 25 de julho de 2012. Altera o Título VI da Parte Especial do Decreto-Lei n ${ }^{\circ} 2.848$, de 7 de dezembro de 1940 - Código Penal, e o art. $1^{\circ}$ da Lei $n^{\circ} 8.072$, de 25 de julho de 1990, que dispóe sobre os crimes hediondos, nos termos do inciso XLIII do art. $5^{\circ} \mathrm{da}$ Constituiçáo Federal e revoga a Lei n ${ }^{\circ}$.252, de $1^{\circ}$ de julho de 1954 , que trata de corrupção de menores. Diário Oficial da União, Brasília, 10 de agosto de 2009.

. Medida Provisória n. 586, de 8 de novembro de 2012. Dispóe sobre o apoio técnico e financeiro da União aos entes federados no âmbito do Pacto Nacional pela Alfabetização na Idade Certa, e dá outras providências. Diário Oficial da União, Brasília, 9 de novembro de 2012.

. Emenda Constitucional n. 59, de 11 de novembro de 2009. Acrescenta $\$ 3^{\circ}$ ao art. 76 do Ato das Disposiçóes Constitucionais Transitórias para reduzir, anualmente, a partir do exercício de 2009, o percentual da Des- 
vinculação das Receitas da Uniáo incidente sobre os recursos destinados à manutenção e desenvolvimento do ensino de que trata o art. 212 da Constituição Federal, dá nova redação aos incisos I e VII do art. 208, de forma a prever a obrigatoriedade do ensino de quatro a dezessete anos e ampliar a abrangência dos programas suplementares para todas as etapas da educação básica, e dá nova redação ao $₫ 4^{\circ}$ do art. 211 e ao $\$ 3^{\circ}$ do art. 212 e ao caput do art. 214, com a inserçáo neste dispositivo de inciso VI. Diário Oficial da União, Brasília, 12 de novembro de 2009.

. Decreto n. 6.286, de 5 de dezembro de 2007. Institui o Programa Saúde na Escola - PSE, e dá outras providências. Diário Oficial da União, Brasília, 6 de dezembro de 2007.

Lei n. 11.180, de 23 de setembro de 2005. Institui o Projeto Escola de Fábrica, autoriza a concessão de bolsas de permanência a estudantes beneficiários do Programa Universidade para Todos PROUNI, institui o Programa de Educação Tutorial - PET, altera a Lei ${ }^{0} 5.537$, de 21 de novembro de 1968, e a Consolidação das Leis do Trabalho - CLT, aprovada pelo Decreto-Lei $\mathrm{n}^{\circ} 5.452$, de $1^{\circ}$ de maio de 1943, e dá outras providências. Diário Oficial da União, Brasília, 26 de setembro de 2005.

Lei n. 10.835, de 8 de janeiro de 2004. Institui a renda básica de cidadania e dá outras providências. Diário Oficial da União, Brasília, 9 de janeiro de 2004.

. Lei n. 10.836, de 9 de janeiro de 2004. Cria o Programa Bolsa Família e dá outras providências. Diário Oficial da União, Brasília, 12 de janeiro de 2004 .

. Decreto n. 5.007, de 8 de março de 2004. Promulga o Protocolo Facultativo à Convenção sobre os Direitos da Criança referente à venda de crianças, à prostituição infantil e à pornografia infantil. Diário Oficial da União, Brasília, 11 de outubro de 1979.

. Lei n. 10.689, de 13 de junho de 2003. Cria o Programa Nacional de Acesso à Alimentação - PNAA. Diário Oficial da União, Brasília, 16 de junho de 2003.

. Lei n. 10.219, de 11 de abril de 2001. Cria o Programa Nacional de Renda Mínima vinculada à educação - «Bolsa Escola», e dá outras providências. Diário Oficial da União, Brasília, 12 de abril de 2001. 
. Medida Provisória n. 2.206-1, de 6 de setembro de 2001. Cria o Programa Bolsa Família e dá outras providências. Diário Oficial da União, Brasília, 10 de setembro de 2001.

. Lei n. 9.394, de 21 de novembro de 1996. Estabelece as diretrizes e bases da educação nacional. Diário Oficial da Uniâo, Brasília, 23 de dezembro de 1996.

. Lei n. 8069, de 13 de julho de 1990. Dispóe sobre o Estatuto da Criança e do Adolescente e dá outras providências. Diário Oficial da Uniáo, Brasília, 16 de julho de 1990 e retificada em 27 de setembro de 1990.

. Decreto n. 99.710, de 21 de novembro de 1990. Promulga a Convenção sobre os Direitos da Criança. Diário Oficial da Uniáo, Brasília, 9 de janeiro de 2004.

- Constituição da República Federativa do Brasil, de 05 de outubro de 1988. Diário Oficial da União, Brasília 05 de outubro de 1988.

. Lei n. 6.697, de 10 de outubro de 1979. Institui o Código de Menores. Diário Oficial da União, Brasília, 11 de outubro de 1979.

. Lei n. 1060, de 5 de fevereiro de 1950. Estabelece normas para a concessão de assistência judiciária aos necessitados. Diário Oficial da União, Brasília, 13 de fevereiro de 1950.

. Decreto-Lei n. 5.452, de $1^{\circ}$ de maio de 1943. Aprova a Consolidação das Leis do Trabalho. Diário Oficial da União, Brasília, 9 de agosto de 1943. . Decreto-Lei n. 2.848, de 7 de dezembro de 1940. Código Penal. Diário Oficial da União, Brasília, 31 de dezembro de 1940.

Capez, F. (2003). Curso de Direito Penal. Vol. I. 6a. ed. São Paulo: Saraiva.

Cury, M. (Coord) (2005). Estatuto da Criança e do Adolescente Comentado. 7a. ed. São Paulo: Malheiros.

Custódio, A.; Veronese, J. (2007). Trabalho Infantil: a negação do ser criança e adolescente no Brasil. Florianópolis: OAB/SC Editora.

Dahlberg, G.; Moss, P; Pence, A. (2003). Qualidade na educação da primeira infância: perspectivas pós-modernas. Porto Alegre: Artmed. 
Gabinete de Documentação de Direito Comparados. Declaração Universal dos Direitos da Criança de 1959. Disponivel em: <http://www.gddc.pt/direitos-humanos/textos-internacionais-dh/tidhuniversais/dc-declaracao-dc. html>. Acesso em 12 de fev. 2013.

Fundo das Nações Unidas para a Infância - UNICEF. Convenção Internacional sobre os Direitos da Criança de 1989. Disponível em: <http://www.unicef. org/brazil/pt/resources_10123.htm>. Acesso em 14 fev. de 2013.

Heywood, C. (2004). Uma história da infância. Porto Alegre: Artmed.

Instituto de Pesquisas Econômicas Aplicadas - IPEA. Estadão Online: Mais da Metade dos Alunos do 9 ${ }^{\circ}$. Ano Querem Trabalhar e Estudar. Disponível em: <http://www.ipea.gov.br/portal/index.php?option=com_content\&view $=$ article $\&$ id $=16870 \&$ catid $=159 \&$ Itemid $=75>$. Acesso em 15 de fev. de 2013.

Instituto Brasileiro de Geografia Estatística - IBGE. Censo 2010 - Indicadores Sociais Municipais: uma análise dos resultados do universo do Censo Demográfico. Tabela 31 - Disponível em: <http://www.ibge.gov.br/home/estatistica/populacao/censo2010/indicadores_sociais_municipais/tabelas_pdf/ tab31.pdf >. Acesso em 09 de fev. 2013.

. IBGE. Censo 2010 - Tabela18 - Taxa de analfabetismo das pessoas de 10 a 17 anos de idade, segundo os municípios pertencentes à região do Semiárido brasileiro - 2010. Disponível em: <http://www.ibge.gov.br/ home/estatistica/populacao/censo2010/indicadores_sociais_municipais/ indicadores_sociais_municipais_tab18_uf_zip.shtm>. Acesso em $03 \mathrm{de} \mathrm{fev.}$ 2013.

IBGE. Sintese de Indicadores Sociais. Disponível em: <http://www. ibge.gov.br/home/estatistica/populacao/condicaodevida/indicadoresminimos/sinteseindicsociais2009/indic_sociais2009.pdf >. Acesso em $04 \mathrm{de} \mathrm{fev.}$ 2013.

(2007). Código Penal Comentado. $7^{\mathrm{a}}$. ed. São Paulo: RT.

Khulmann Jr., M. (1998). Infância e educação infantil - uma abordagem histórica. Porto Alegre: Mediação.

Moura, E. (2000). Crianças operárias na recém-industrializada São Paulo. In: PRIORE, M. (Org.). História das crianças no Brasil. São Paulo: Contexto, pp. 259-286. 
Ministério da Justiça - Portal do Cidadão. Declaração Universal dos Direitos Humanos. Disponivel em: <http://portal.mj.gov.br/sedh/ct/legis_intern/ ddh_bib_inter_universal.htm>. Acesso em 17 de fev. 2013.

Ministério do Trabalho e Emprego - MTE. Plano de Prevenção do Trabalho Infantil e Proteção ao Trabalhador Adolescente. Disponível em: <http:// portal.mte.gov.br/data/files/FF8080812BCB2790012BD5189CAB12D1/ pub_6361.pdf>. Acesso em 05 de fev. de 2013.

- Quadro Geral das Operaçóes de Fiscalização para Erradicação do Trabalho Escravo - Sit/Srte 1995-2012. Disponível em: <http://portal.mte. gov.br/trab_escravo/resultados-das-operacoes-de-fiscalizacao-para-erradicacao-do-trabalho-escravo.htm>. Acesso em 06 de fev. de 2013.

. Mapas de Indicativos do Trabalho da Criança e do Adolescente.

Disponível em: $<$ http://portal.mte.gov.br/geral/mapa-de-indicativos-versao-2005. htm>. Acesso em 30 de jan. de 2013.

Nucci, G. (2007). Código Penal Comentado. $7^{a}$ ed. São Paulo: RT.

Nucci, G. (2010). Código Penal Comentado. 10ª ed. Sáo Paulo: RT.

Organização Internacional do Trabalho - OIT - Escritório no Brasil. Convençôes Ratificadas pelo Brasil. Disponível em: <http://www.oit.org.br/convention>. Acesso em 08 de fev. de 2013.

Priore, M. Del (Org.) (1999). História das crianças no Brasil. São Paulo: Contexto.

Ramos, F. P. (2000). A história trágico-maritima das crianças nas embarcaçóes portuguesas do século XVI. In: PRIORE, M. (Org.). História das Crianças no Brasil. Sáo Paulo: Contexto, pp. 19-54.

Rizzini, I. (2000). Pequenos trabalhadores do Brasil. In: PRIORE, M. (Org.). História das Crianças no Brasil. São Paulo: Contexto, pp. 376-406.

Rousseau, Jean-Jacques (1995). Emílio, ou Da educação. Tradução de Elia Ferreira Edel. $3^{\mathrm{a}}$ ed. Rio de Janeiro: Bertrand Brasil.

Scliar, M. (1995). Um país chamado infância. São Paulo: Ática.

Sociedade Brasileira de Defesa da Criança e do Adolescente; Forum Nacional da Defesa dos Direitos da Criança e do Adolescente (2011). CADÊ? Crianças e Adolescentes em Dados e Estatísticas. Brasília: FNDCA. 